\title{
Three bird species new to Brazil from the Serra da Mocidade, a remote mountain in Roraima
}

\author{
Thiago Orsi Laranjeiras ${ }^{1,2,3,8}$, Ramiro Dário Melinski ${ }^{1,3}$, Luciano Nicolas Naka ${ }^{4}$, Gabriel Augusto Leite ${ }^{1,5}$, \\ Gisiane Rodrigues Lima ${ }^{1,6}$, José Anselmo d'Affonseca-Neto ${ }^{7} \&$ Mario Cohn-Haft ${ }^{1}$
}

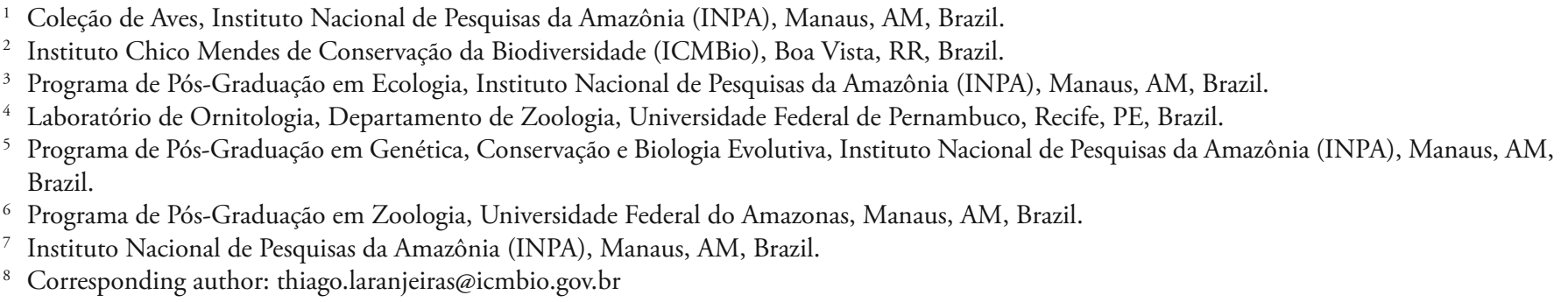

Received on 03 September 2019. Accepted on 30 September 2019.

\begin{abstract}
From 15 January to 06 February 2016, we conducted an expedition to the Serra da Mocidade, a remote and previously unexplored mountain range in extreme northern Amazonian Brazil. There we encountered three bird species never before documented in Brazilian territory: Grallaria guatimalensis (Grallariidae) was photographed, audio recorded, video recorded and a single specimen collected; Catharus aurantiirostris (Turdidae) was similarly documented and a series of specimens collected; and a single individual of Parkesia motacilla (Parulidae) was photographed. All were found in the understory of montane forest at 1000-1550 m elevation. We interpret each of these as most likely representing a regularly occurring population on Mocidade. However, each had probably been overlooked in Brazil for a different reason and represents a distinct distributional pattern. Adding these novelties to Brazil's previously published total of 1919 species clearly expresses the country's position among the most bird-rich in the world, perhaps the richest, and suggests that further exploration of Brazil's Amazonian mountains will yield more discoveries.
\end{abstract}

KEY-WORDS: Amazonia, Catharus aurantiirostris, Grallaria guatimalensis, montane forest, Parkesia motacilla, tepui avifauna.

\section{INTRODUCTION}

The number of bird species documented within Brazilian territory has grown considerably in recent years, as reported regularly by the Comitê Brasileiro de Registros Ornitológicos (CBRO - Brazilian Bird Records Committee; Piacentini et al. 2015). There are basically three ways by which an avifauna may increase over time: the discovery of new species, taxonomic revision (elevating subspecies to species level), or simply by documenting the presence of species known from other countries but never before found in the one in question. Brazil is clearly a current hotspot for the discovery of new species (see Whitney \& Cohn-Haft 2013), and 15\% of the twenty species added in the last country-wide revision were species new to science (Piacentini et al. 2015). Similarly, recent taxonomic revisions have led to the splitting of widespread species into numerous more restricted-range ones (e.g., Rodrigues et al. 2013, Rego et al. 2014, Lopes \& Gonzaga 2016), including 75\% of the latest increase. This is especially prevalent in the Amazon, where the enormous territorial extent and presence of numerous areas of endemism within Brazil are likely to continue to produce major revisions in taxonomy and increases in total species numbers for some time to come.

The third mode, documenting range extensions into Brazil, is currently the least common, accounting for only $10 \%$ of recent additions (Piacentini et al. 2015). Such discoveries are of course most likely near international borders and for species that are especially difficult to identify or that occupy habitats still poorly explored within the country. Amazonian montane forests (above $1000 \mathrm{~m}$ a.s.l.) have barely been studied within Brazil (Novaes 1965, Dickerman \& Phelps-Jr. 1982, Borges et al. 2014). They are found in a region known as "Pantepui", a complex of ancient sandstone table-top mountains (called "tepuis") and other geologically distinct mountains, located in southern and eastern Venezuela, Guyana, Surinam, and adjacent parts of Brazil (Mayr \& Phelps-Jr. 1967). Based predominantly on studies from Venezuela (see references in Mayr \& Phelps-Jr. 1967 and in Hilty 2003), these montane forests are known to have 
an avifauna distinct from that of the Amazonian lowlands and with a high degree of endemism. Outside of Venezuela, there have been only a few recent ornithological studies in Guyana (Braun et al. 2003, Robbins et al. 2007) and Suriname (Zyskowski et al. 2011); most montane habitat on the Brazilian side of these countries' borders remains unexplored (but see Borges et al. 2014). Thus, the mountains of northern Brazil are likely places to find bird species previously undetected in the country.

\section{METHODS}

Our expedition to the Serra da Mocidade, a remote and previously unexplored mountain range in the state of Roraima in extreme northern Amazonian Brazil (Fig. 1), took place from 15 January to 06 February 2016, including surveys around two camps: "Camp 1" at $600 \mathrm{~m}$ a.s.l. and "Camp 2" at $1000 \mathrm{~m}$ a.s.l. We spent 12 days working above $1000 \mathrm{~m}$ elevation $\left(1^{\circ} 42^{\prime} \mathrm{N} ; 61^{\circ} 47^{\prime} \mathrm{W}\right)$, with trails accessing a peak over $1700 \mathrm{~m}$ a.s.l. A multidisciplinary group of colleagues conducted inventories of a variety of animal, plant, and mineral groups, mostly to be reported elsewhere after more detailed analyses. However, one immediate and striking result of the expedition was the documentation of three bird species not previously recognized in the Brazilian avifauna. Here, we present this documentation and discuss briefly the relevance of each case, including the possible population and conservation status of these species in Brazil.

\section{RESULTS AND DISCUSSION}

\section{Scaled Antpitta (Grallaria guatimalensis)}

On 29 January 2016, Cohn-Haft, Naka, and Marcos Amend encountered a single individual of Grallaria guatimalensis. It was first seen perched on a large rock in a stream below a small waterfall at just over 1000 m elevation. From there it hopped out of sight under an overhanging boulder and then reappeared in the adjacent understory, moving in a seemingly tame and undisturbed fashion on or near the ground. It was subsequently collected (see Appendix I for specimen data). A second individual was encountered by Leite on 31 January, some $2 \mathrm{~km}$ away in a dry-bottom ravine at about $1300 \mathrm{~m}$ elevation, after repeated "trolling" with playback at different sites, using other recordings from northern South America. The bird responded by vocalizing (see XC461791 at xeno-canto. org) and approaching. It finally revealed itself in the fork of a trunk, $3 \mathrm{~m}$ above ground, where it remained for some

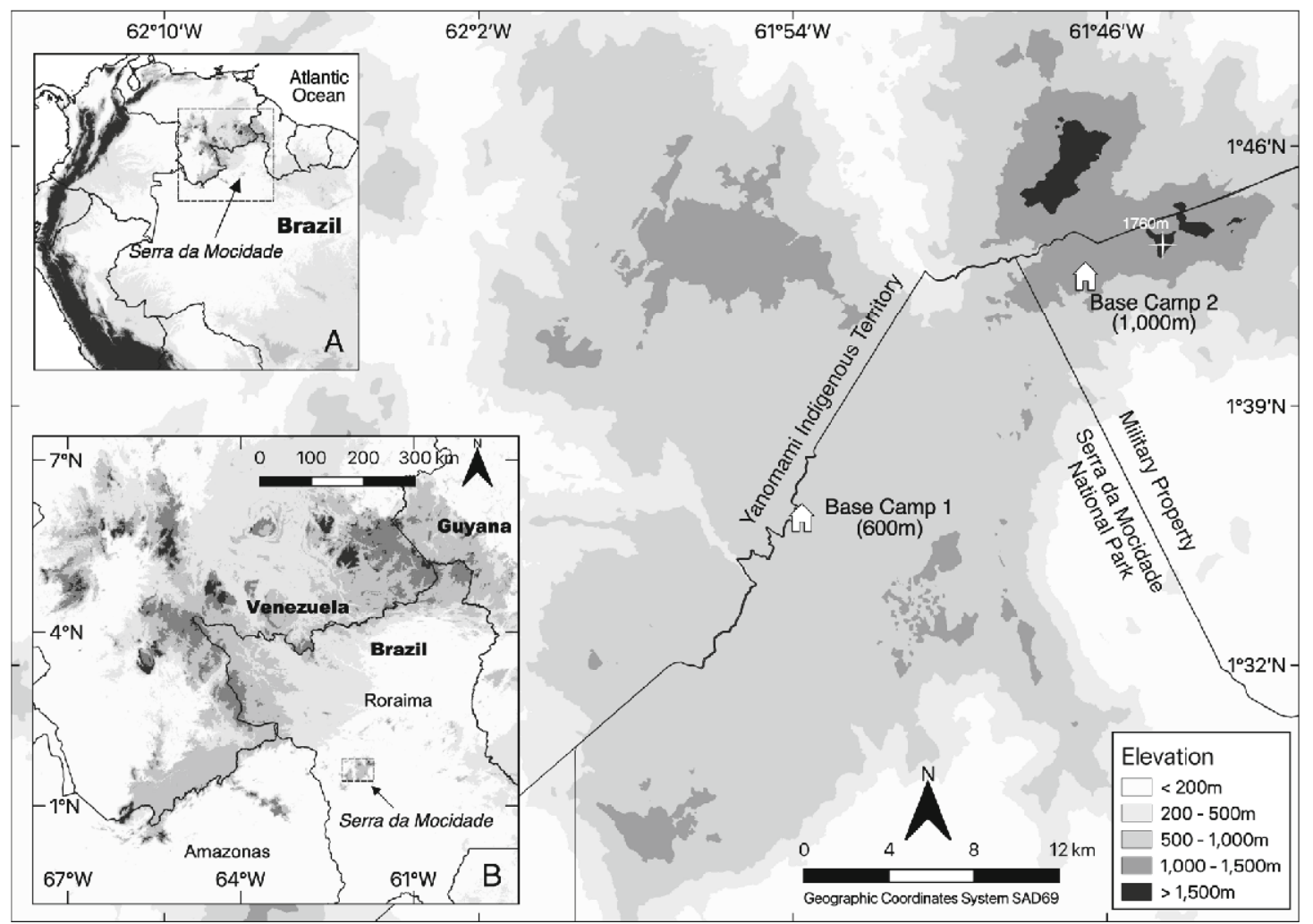

Figure 1. The Serra da Mocidade mountain range in the context of northern South America (inset A, where square delimits area detailed in inset B) and of Pantepui (inset B, where dashed square delimits that part of the Serra detailed in the main figure), showing elevational ranges above sea level. All the species mentioned here were found near Base Camp 2 and trails between camp and the 1760 $\mathrm{m}$ peak to the east. 
10 min and was photographed (Fig. 2) and filmed (see IBC1570323 at hbw.com/ibc/), before dropping to the ground and moving out of sight.

This species is known from forest understory in montane areas (mostly 500-2500 m) over an extensive distribution in Central America and northern South America, including the Andes and tepuis (Greeney 2018). Nine subspecies are currently accepted, showing considerable variation in size and coloration (Krabbe \& Schulenberg 2016). The only subspecies recognized from

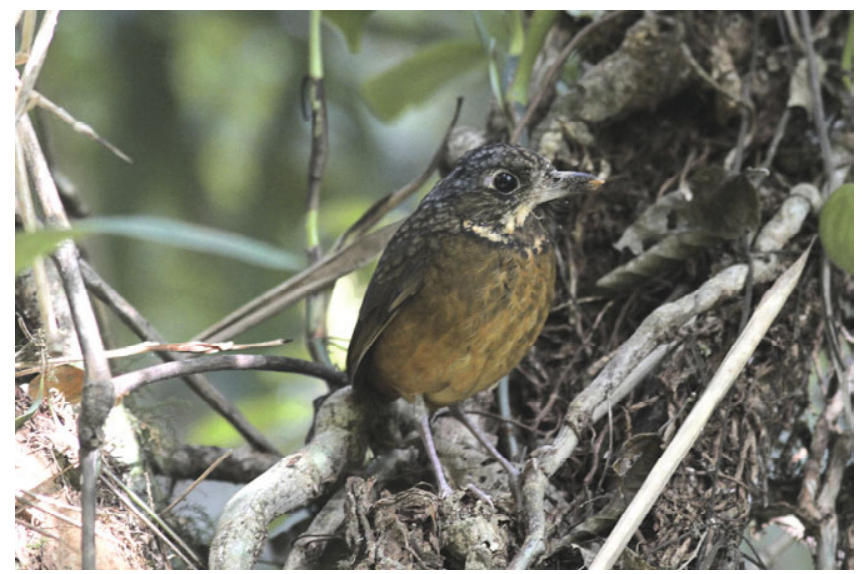

Figure 2. Scaled Antpitta (Grallaria guatimalensis) at approximately $1300 \mathrm{~m}$ elevation on the Serra da Mocidade. Photo author: Gabriel Leite.
Pantepui, G. g. roraimae, is poorly known with local but probably widespread occurrence in the region (Braun et al. 2003, Hilty 2003). Although we have not yet had an opportunity to compare carefully our specimen, photographs, or recordings to others, the gray crown and overall orangey ventral coloration of the birds on Serra da Mocidade jibe with characteristics described for the expected subspecies, G. g. roraimae (Greeney 2018). Molecular studies of the species across its range are currently in course (Gustavo Bravo, pers. comm.) and suggest that more than one species-level taxon is involved.

Although an earlier reference to its presence in Brazil (Mayr \& Phelps-Jr. 1967) was shown to be the result of misidentification (Mallet-Rodrigues \& Pacheco 2003), this species' occurrence in the country was to be expected, considering its widespread distribution elsewhere in Pantepui (Hilty 2003). Our observations represent a range extension of some $280 \mathrm{~km}$ (Fig. 3) and suggest that the Brazilian Pantepui comprises an important part of this taxon's range. The scarcity of detections (only two) during the expedition could be a result of little vocal activity at this time of year or of local rarity. Even if the species is uncommon locally, rather than merely difficult to detect as we suspect, the overwhelmingly intact state of montane forests in the region should sustain natural population densities. This corroborates a "Least

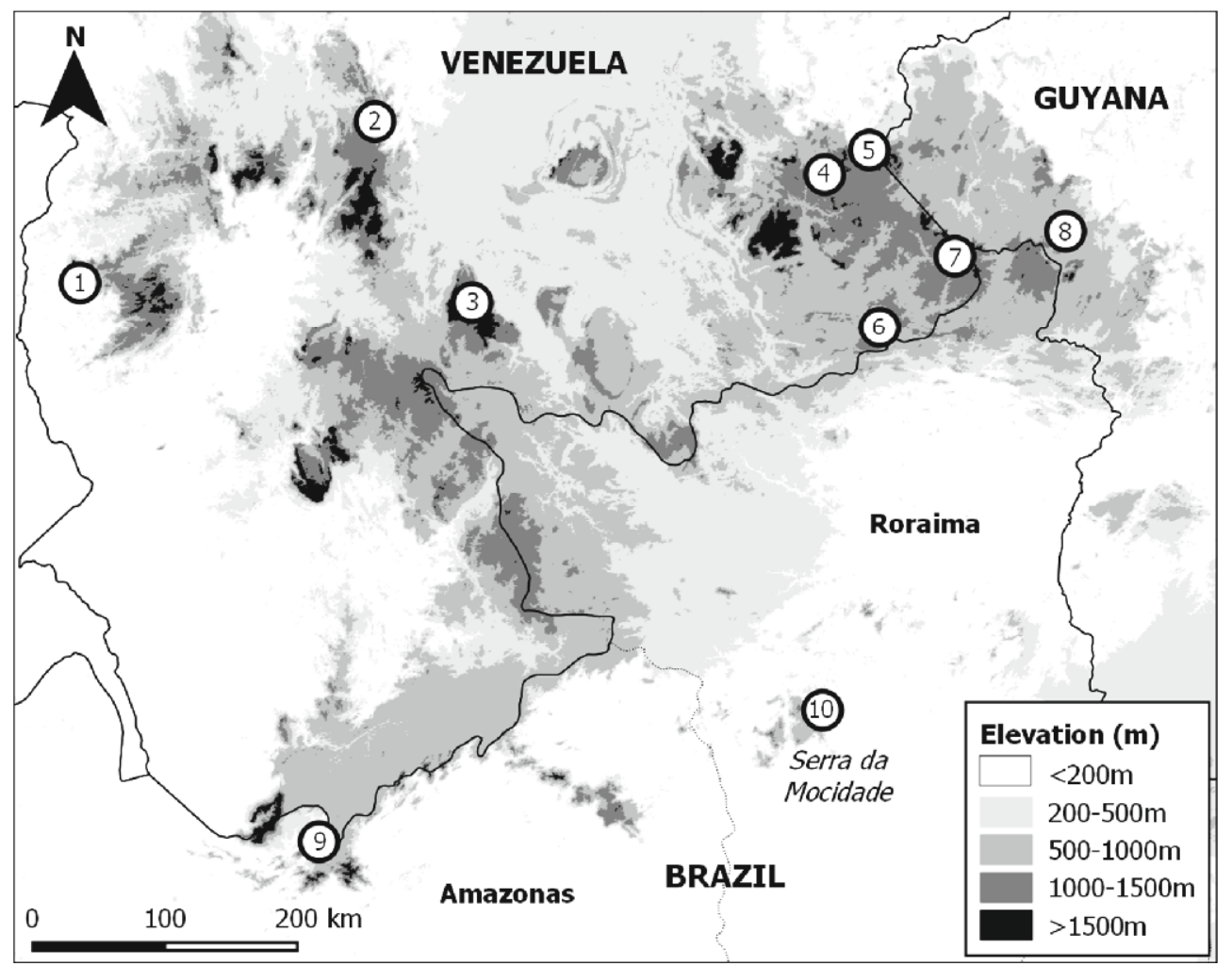

Figure 3. Known localities of the tepui endemic Grallaria guatimalensis roraimae, the only subspecies of Scaled Antpitta known from Pantepui. Numbers refer to localities as follows: 1) Cerro Paraque (Mayr \& Phelps-Jr. 1967, Greeney 2018), 2) Cerro Tabaro (Hilty 2003), 3) Cerro Jaua (Hilty 2003), 4) Ptari-tepui (Hilty 2003), 5) Sierra de Lema (Hilty 2003, Klaiber 2015), 6) Paurai-tepui (Crease 2011), 7) Mount Roraima (Chapman 1931, Braun et al. 2003), 8) Mount Ayanganna (Milensky et al. 2016), 9) Sierra Imeri (Mayr \& Phelps-Jr. 1967), 10) Serra da Mocidade (this study). 
Concern" threat status for the species in Brazil, as already recognized globally (BirdLife International 2019). In the absence of any prior common name in Portuguese, we propose Tovacuçu-do-tepui, "Tovacuçu" being the name used generically in Brazil for the other resident Grallaria species.

\section{Orange-billed Nightingale-Thrush (Catharus aurantiirostris)}

Laranjeiras first observed this species on 16 January 2016. While cutting a trail through unbroken forest along a slope at about $1400 \mathrm{~m}$ elevation, he heard an unfamiliar vocalization which he imitated whistling. An individual of this species approached, perching calmly on a horizontal branch, $2 \mathrm{~m}$ above ground in lightly shaded understory, dense with slender bamboos (Chusquea spp.). Shortly afterwards, along the same trail and in similar habitat, another individual was observed, perched near the ground, showing the same quiet and inconspicuous behavior. Over the following weeks, members of our ornithological team observed this species daily, frequently singing, moderately responsive to playback, and present in considerable numbers at different points between 1100 and $1550 \mathrm{~m}$ a.s.l., especially but not exclusively where bamboo dominated the understory. In general, we encountered single individuals (at most two) at any given spot, and they seemed to be more or less continuously distributed through the forest in preferred habitat. We obtained numerous photos (Fig. 4; see also WA3461246 at wikiaves.com.br) and recordings of vocalizations (see XC461792, XC493456, XC493458, XC493459 at xenocanto.org), and we collected a series of nine specimens (see Appendix I for specimen data).

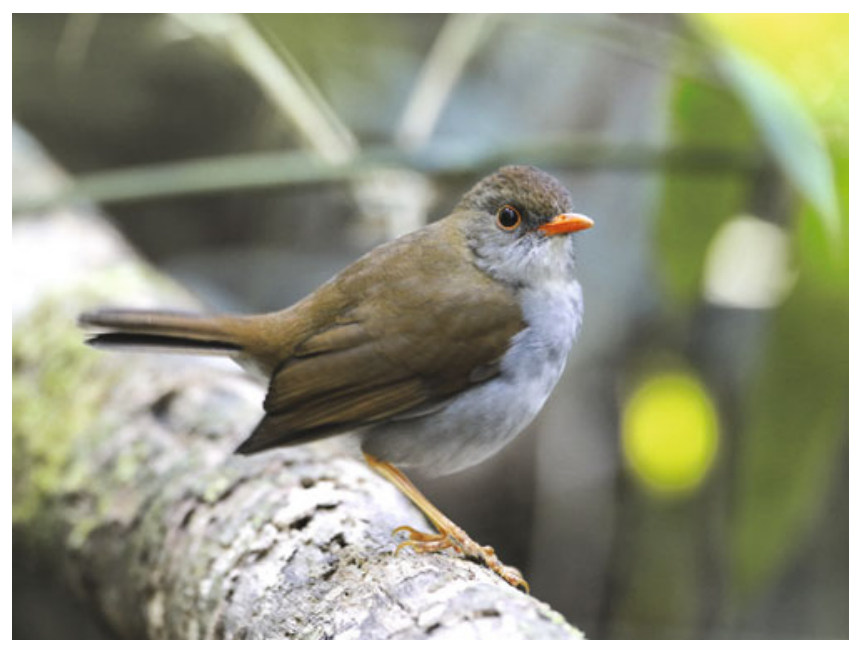

Figure 4. Orange-billed Nightingale-Thrush (Catharus aurantiirostris) from the Serra da Mocidade, showing brown crown typical of those populations found nearest in northern Venezuela and eastern Colombia. Photo author: Anselmo d'Affonseca.
The occurrence of $C$. aurantiirostris in the Serra da Mocidade is intriguing. As in G. guatimalensis, this species is resident in montane areas (mostly 600-2900 m) in Central America and northern South America, where a total of 11 subspecies are recognized (Collar 2016). However, unlike the antpitta, this thrush was completely unknown from the Pantepui region. Serra da Mocidade is almost $1000 \mathrm{~km}$ from the nearest reported site of occurrence, in northern Venezuela (Collar 2016), and in the intervening area there are hundreds of kilometers of seemingly suitable montane habitat in the Venezuelan tepuis, some of which at least have been reasonably well studied (Fig. 5). We find it unlikely that the species could have been overlooked at other sites if it were as common and conspicuous as we found it at Mocidade.

Several alternative hypotheses might explain this gap. One is that the population we found is only temporarily present, the result of an as yet, undocumented seasonal migration from the Andes into the tepuis. In this case, the species may indeed be present throughout the intervening areas, but perhaps was not detected elsewhere due to surveys at the wrong times of year. The species is known to migrate elsewhere, at least short distances up and down slopes (Collar 2016). The presence of moderate or heavy fat in two of the nine specimens is consistent with migratory behavior, considering that most resident Amazonian birds show little or no fat accumulation (Johnson et al. 2012). However, the variability in fat stores among the specimens, with four having trace or little fat, is more difficult to explain. Although it seems unlikely to us that such annual migrants throughout the tepuis would have passed unnoticed elsewhere, documenting the presence or absence of this species on Mocidade at other times of year would be illuminating, as would searches for it on other nearby mountains at the same time of year. We found no unambiguous evidence of breeding, such as nesting or breeding-condition adults (based on size and state of gonads and lack of brood patches) or fledglings (based on overall plumage and molt pattern, lack of gapes and of bursae, moderate to complete skull ossification), and so we cannot eliminate the possibility of a migrant, non-breeding population.

Another possibility is that we stumbled onto a temporary or new population during a rare and irregular incursion or colonization event, not likely to be repeated and as such never before documented. Although we also cannot rule out this possibility, much more information over longer periods and more locations would be necessary to demonstrate witnessing such a rare event. Considering how poorly studied even the best-known Amazonian sites are, let alone remote Amazonian mountains, we are inclined to interpret events during this and other expeditions as typical of normal, regularly occurring phenomena until proven to the contrary. 


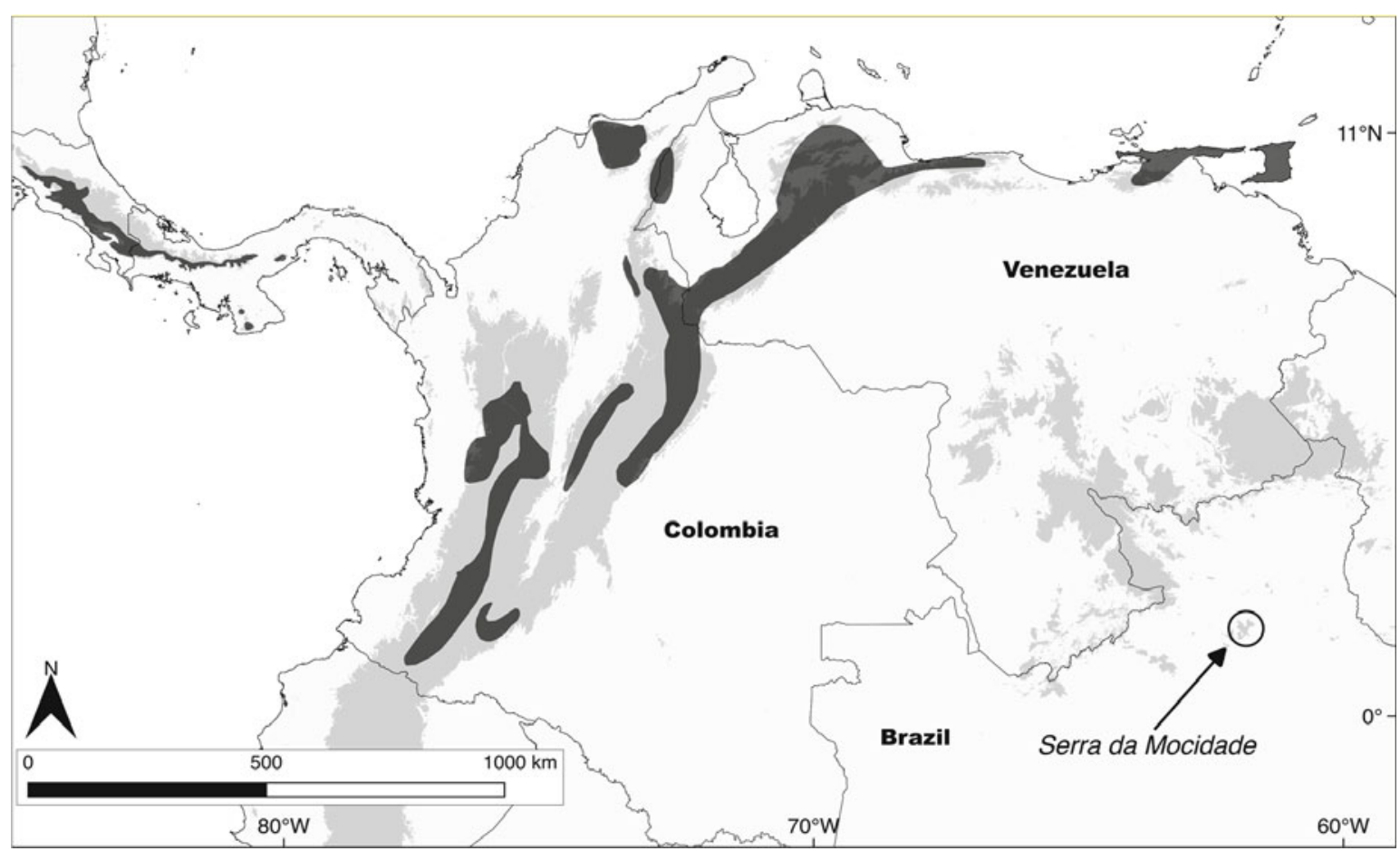

Figure 5. Distribution of Catharus aurantiirostris as previously known (black polygons, from xeno-canto.org, based on BirdLife International 2016) and at Serra da Mocidade (black circle), superimposed on highland areas (gray areas, above $600 \mathrm{~m}$ elevation) of Central America and northern South America. Note large distributional gap in the Pantepui highlands north and west of Mocidade.

Finally, and what we believe to be the most likely explanation for the presence of $C$. aurantiirostris in our study area, is that indeed the species colonized Mocidade without colonizing other localities within Pantepui, or was once present more widely but went locally extinct elsewhere and persisted on Mocidade, presumably because of this mountain range's large size and distance from other mountains, where extinction factors for whatever reason did not affect Mocidade. Active singing, fairly uniform spacing among individuals, and the tendency to approach after playback all suggest to us a resident population of territorial individuals or pairs, albeit not breeding at the time of our expedition. Documenting reproduction at the site should be a priority of future expeditions to help settle the question of the status of this population.

Phenotypic similarity of these birds (Fig. 4) to descriptions of several populations found at the nearest known localities (Collar 2016) does not permit taxonomic conclusions without direct comparison among specimens. Genetic studies underway (Matthew Halley, pers. comm.) should help elucidate the origin, age, and taxonomic status of the Mocidade population as well as permit identification of demographic processes relevant to diversification within this polytypic species.

As a Portuguese common name, we propose Sabiazinho-de-bico-laranja, meaning "small orange-billed thrush". If the Mocidade population should prove to be a distinct species, then we would suggest calling it Sabiazinho-da-Mocidade. Furthermore, we suggest that this diminutive noun form, sabiazinho, be used for all Catharus thrushes in recognition of their smaller size and different plumage patterns compared with Turdus spp., which are called sabiás in Portuguese.

Assuming that this thrush occurs throughout Mocidade in appropriate habitat, then even if it only occurs on Mocidade, within Brazil, it should nevertheless have a significantly large population. Regardless of taxonomic status, and despite the relatively small total area of montane habitat on Serra da Mocidade (about 100 $\mathrm{km}^{2}$ above $1100 \mathrm{~m}$ ), there is no evidence of threat, or even human presence, in its purported range. Thus, we suggest this species be categorized as "Least Concern" at the national level, consistent with its global listing (BirdLife International 2019). However, we also recognize that this scenario could rapidly change under new environmental conditions due to climate change. The Brazilian state of Roraima is witnessing more often and more dramatic droughts related to "El Niño Southern Oscillation" events (Cochrane \& Schulze 1998, Fonseca et al. 2017), and wild fires now often spread across large portions of the state. It is not unthinkable that a couple of severe droughts could allow the arrival of fire into Mocidade, despite its current relatively humid environment and lack of human presence (Fonseca et al. 2017). Therefore, while we believe these populations do not face an imminent threat, the very limited suitable area for this species in the country $\left(\sim 100 \mathrm{~km}^{2}\right)$ could be a cause of concern in the near future. 


\section{Louisiana Waterthrush (Parkesia motacilla)}

On 01 February 2016, while actively photographing birds, d'Affonseca-Neto observed an unfamiliar passerine along a flat and relatively straight stretch of a narrow (3-5 $\mathrm{m}$ wide), shallow (10-50 cm deep), fast-moving stream at $1050 \mathrm{~m}$ a.s.l. The bird appeared to be foraging for small arthropods while hopping through overhanging branches and roots less than $1 \mathrm{~m}$ above the stream. During the few minutes that the bird was present, d'Affonseca-Neto took pictures at fairly close range (Fig. 6), which we identified later that day as $P$. motacilla. On the following days, we made repeated unsuccessful attempts to relocate the bird, including using mist nets along the stream.

The long supercilium, which is narrower and faintly buffy anterior to the eye, white and increasingly wide posterior to the eye, is a diagnostic feature relative to $P$. noveboracensis (Sibley 2012), a very similar-looking species known elsewhere in Brazil. Other useful marks include the predominantly white ventral ground color, unstreaked throat and undertail coverts, strong and continuous dark line bordering throat, and subtly contrasting buffy tone to lower flanks. The overall pattern of ventral streaking, with relatively sparse, broad streaks, forming two roughly parallel lines along the lower flanks is also characteristic. Finally, an interesting feature proposed by Roeder \& Moores (2007), of primary projection (beyond tertials) roughly equal to tertial projection (beyond the greater coverts) in $P$. motacilla (as opposed to much shorter relative primary projection in $P$. noveboracensis), is also upheld in this individual (Fig. 6).

To our knowledge, this is the first documented record of Louisiana Waterthrush in Brazil or from the Pantepui region, and one of the few records from anywhere in South America. The species mostly winters in Central America and the Caribbean, but may be regular in extreme northern Venezuela (Hilty 2003,
Mattsson et al. 2009). It is of course impossible to know if our single observation represents a very rare occurrence, or if lack of coverage and lack of familiarity with the species' identification are responsible for overlooking what could be a regular wintering population. Its only congener, the Northern Waterthrush (P. noveboracensis), is itself an uncommon but regular winterer in northern Brazil, including elsewhere during this same expedition (see below). Careful attention by observers to diagnostic marks separating the two (see above) may lead to more correct identifications in the future.

In the breeding range, the two waterthrushes separate by habitat, $P$. noveboracensis on slack water, beaver ponds and lakesides, $P$. motacilla along small, fastrunning, forested streams with cut banks and exposed roots (Mattsson et al. 2009, Whitaker \& Eaton 2014), much like where our observation was made. Consistent with this, most of our observations of $P$. noveboracensis in South America (unpub. data) have been along large lowland rivers or in mangrove swamps. Our one record of that species during the Serra da Mocidade expedition was at a lower site (Base Camp 1, 600 m a.s.l.; Fig. 1), along a flat stretch of the Rio Pacu, considerably larger, slower, and more exposed to the sun than the stream where $P$. motacilla appeared. If this habitat distinction persists on the wintering grounds as our observations suggest, and if $P$. motacilla does occur regularly in northern South America, then it is likely to be found most in montane areas and, in Brazil, to be restricted to Pantepui. Thus, it is best treated as either an extralimital vagrant or a regular migrant of least conservation concern in Brazil, consistent with its global status (BirdLife International 2019). We propose the Portuguese name Abana-rabo-daserra, meaning "montane tail-wagger". Consistent with that and in recognition of the distinctive tail wagging behavior in this genus, we also propose changing the Portuguese name of $P$. noveboracensis from Mariquita-
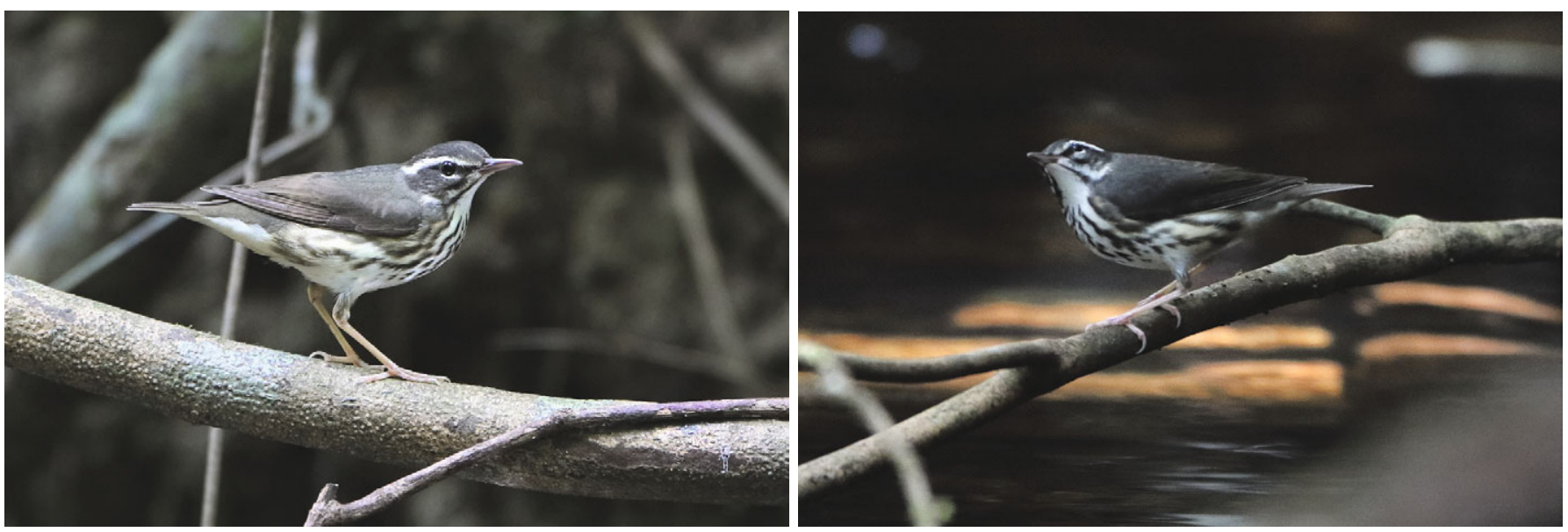

Figure 6. Two angles of the Louisiana Watertrush (Parkesia motacilla) found on the Serra da Mocidade, showing many of the diagnostic features (see text), separating this species from its only congener, the Northern Waterthrush (P. noveboracensis). Photo author: Anselmo d'Affonseca. 
boreal (which could be applied equally to virtually all of the migrant warblers from North America) to Abanarabo-da-baixada.

\section{Final considerations}

Along with its neighbors, Colombia and Peru, Brazil is among the three countries with the greatest diversity of birds in the world. However, the counts vary considerably, especially depending on taxonomy, about which there is rarely complete consensus. Attempts to list the species of these countries applying a uniform taxonomic scheme across them come up with different totals and rankings: Colombia 1877 species, Peru 1855, Brazil 1809 (BirdLife International 2017); Colombia 1851, Brazil 1818, Peru 1802 (Avendaño et al. 2018, Pacheco \& Agne 2019, Plenge et al. 2018, respectively, using Remsen-Jr. et al. 2019). However, Brazil's ornithological records committee (Piacentini et al. 2015) lists 1919 species for the country, reflecting numerous taxonomic splits not yet adopted globally. With the addition of the three species reported here and others reported elsewhere (CBRO, in prep.), Brazil's total avifauna rises to 1938 species (not including splits). Brazil's total avifauna rises to 1922 species. Similar in-country efforts in Colombia to compile that country's avifauna report totals of 1909 (Avendaño et al. 2017) and 1937 (Donegan et al. 2016), suggesting minimal difference between Brazil and Colombia using current knowledge and similar taxonomic approaches. Based on sheer geographic area, Brazil (roughly eight and seven times greater than Colombia and Peru, respectively) is indeed likely to contain the highest bird diversity of any country.

Finding, in a single expedition, three species new to the already rich Brazilian avifauna, all possibly of regular occurrence in the region, demonstrates just how little is known about Amazonian montane birds. We made a comparable sampling effort at a lower elevation site $(600 \mathrm{~m}$, Base Camp 1) during the same trip, with no species new for Brazil (but with several range, habitat, and elevation extensions, to be presented elsewhere). This suggests that indeed it is the montane fauna per se, and not just any previously unexplored Amazonian site, that especially needs work.

Each of the three novelties represents a different pattern of occurrence that might help direct future research. As was the case with G. guatimalensis, there are still several resident bird species in the tepuis of Venezuela that have not yet been confirmed in Brazil, including Polytmus milleri and Grallaricula nana (Naka et al. 2006). North American migrants, like P. motacilla, with a preference for montane wintering grounds in northern South America, include Contopus sordidulus, still awaiting confirmation in Brazil, and Setophaga cerulea, recently confirmed (Farias \& Dapaz 2019). Most resident Andean bird species are not known from the tepuis, and predicting which of these might actually have isolated populations somewhere in Amazonian Brazilian mountains, as appears to be the case with $C$. aurantiirostis, is much more difficult. However, there are other cases of predominantly Andean birds also known from few or single Pantepui localities; examples include Dysithamnus leucostictus (Zyskowsky et al. 2011) and Phyllomyias zeledoni (Wetmore \& Phelps-Jr. 1956, Hilty 2003). Further additions to the Brazilian avifauna, thus, are a likely side effect of continued research in Amazonian mountains. We believe this intriguingly understudied realm deserves increased attention.

\section{ACKNOWLEDGEMENTS}

This paper is dedicated to the memory of Haroldo Palo-Jr. (1953-2017), co-expedition member, friend, colleague, and inspiration to us all. This is contribution 49 of the Amazonian Ornithology Technical Series of the INPA Zoological Collections Program. The Expedition "Biodiversity of the Serra da Mocidade" was the result of a collaboration between the Instituto Nacional de Pesquisas da Amazônia (INPA), Instituto Chico Mendes de Conservação da Biodiversidade (ICMBio), Comando Militar da Amazônia (CMA), and Grifa Filmes. We are especially grateful to Maurício Dias for his interest in documenting the expedition and his active and successful fundraising; to General Theóphilo for including the expedition in the "Proamazônia" program; to General Franklimberg for help getting over innumerable logistical and institutional hurdles; to Lieutenant Coronel Fábio Costa, Lieutentant Coronel Edson Souto, and the Brazilian Army's Fourth Aviation Battalion (4 $\left.4^{\circ} \mathrm{BAvEx}\right)$ for incomparable helicopter support and dedication to the safety of all expedition participants; to Sargento Rabello and his crew for help in scouting and preexpedition preparation; to photographers Marcos Amend and Haroldo Palo-Jr. for accompanying the bird crew and photographing birds whenever possible; to Juruna, Pinduca, other field assistants and cooks for their indispensable help; and to all the other biologists that interacted productively with us, especially Angêla dos Santos, Cassiano Gatto, Mateus Ferreira and Roberta Canton of the bird crew. Marco Aurélio Silva and Ingrid Macedo helped incorporating specimens into the INPA collection, and Paulo Massoca and João Vitor "J.B." Campos e Silva helped immeasurably during earlier expedition planning stages. Harold Greeney generously shared locality data of Grallaria, and Vitor Piacentini helped calculate species richness data. Special thanks go to the staff of the Parque Nacional da Serra da Mocidade, including Park Director Inara Santos for sharing the dream and the "tambaqui", as well as Romério Briglia Ferreira and Erica Fujisaki for helping with permits and every detail of the expedition. 


\section{REFERENCES}

Avendaño J.E., Bohórquez C.I., Rosselli L., Arzuza-Buelvas D., Estela F.A., Cuervo A.M., Stiles F.G. \& Renjifo L.M. 2017. Lista de chequeo de las aves de Colombia: una síntesis del estado del conocimiento desde Hilty \& Brown (1986). Ornitología Colombiana 16: eAO1.

Avendaño J.E., Bohórquez C.I., Russelli L., Arzuza-Buelvas D., Estela F.A., Cuervo A.M., Stiles F.G. \& Renjifo L.M. 2018. Species lists of birds for South American countries and territories: Colombia. http:// www.museum.lsu.edu/ - Remsen/SACCCountryLists.htm (Access on 31 August 2019).

BirdLife International. 2016. Bird species distribution maps of the world. http://datazone.birdlife.org/species/requestdis (Access on 31 August 2019).

BirdLife International. 2017. Country profiles: Brazil, Colombia, Peru. http://datazone.birdlife.org/country (Access on 30 April 2017).

BirdLife International. 2019. IUCN Red List for birds. http://www. birdlife.org on (Access on 31 August 2019).

Borges S.H., Whittaker A. \& Almeida R.A.M.D. 2014. Bird diversity in the Serra do Aracá region, northwestern Brazilian Amazon: preliminary check-list with considerations on biogeography and conservation. Zoologia 31: 343-360.

Braun M.J., Robbins M.B., Milensky C.M., O'Shea B.J., Barber B.R., Hinds W. \& Prince W.S. 2003. New birds from Guyana from Mts. Roraima and Ayanganna. Bulletin of the British Ornithologists' Club 123: 24-33.

Chapman F.M. 1931. The upper zonal bird-life of Mts. Roraima and Duida. Bulletin of the American Museum of Natural History 63: $1-135$.

Cochrane M.A. \& Schulze M.D. 1998. Forest fires in the Brazilian Amazon. Conservation Biology 12: 948-950.

Collar N. 2016. Orange-billed Nightingale-thrush (Catharus aurantiirostris). In: del Hoyo J., Elliott A., Sargatal J., Christie D.A. \& de Juana E. (eds.). Handbook of the birds of the world alive. Barcelona: Lynx Editions. http://www.hbw.com/node/58366 (Access on 04 November 2016).

Crease A. 2011. [XC114371, Grallaria guatimalensis]. www.xenocanto.org/114371 (Access on 31 August 2019).

Dickerman R.W. \& Phelps-Jr. W.H. 1982. An annotated list of the birds of Cerro Urutaní on the border of Estado Bolívar, Venezuela, and Territorio Roraima, Brazil. American Museum Novitates 2732: $1-20$.

Donegan T., Verhelst J.C., Ellery T., Cortés-Herrera O. \& Salaman P. 2016. Revision of the status of bird species occurring or reported in Colombia 2016 and assessment of BirdLife International's new parrot taxonomy. Conservación Colombiana 24: 12-36.

Farias F.B. \& Dalpaz L. 2019. First documented record of Cerulean Warbler Setophaga cerulea (Parulidae) in Brazil. Revista Brasileira de Ornitologia 27: 132-134.

Fonseca M.G., Anderson L.O., Arai E., Shimabukuro Y.E., Xaud H.A., Xaud M.R., Madani N., Wagner F.H. \& Aragáo L.E. 2017. Climatic and anthropogenic drivers of northern Amazon fires during the 2015-2016 El Nińo event. Ecological Applications 27: 2514-2527.

Greeney H. 2018. Antpittas and gnateaters. London: Bloomsbury Publishing.

Hilty S.L. 2003. Birds of Venezuela, $2^{\text {nd }}$ edn. Princeton: Princeton University Press.

Johnson E.I., Stouffer P.C. \& Bierregaard-Jr. R.O. 2012. The phenology of molting, breeding and their overlap in central Amazonian birds. Journal of Avian Biology 43: 141-154.

Klaiber J. 2015. [XC214759, Grallaria guatimalensis]. www.xenocanto.org/214759 (Access on 31 August 2019).
Krabbe N.K. \& Schulenberg T.S. 2016. Scaled Antpitta (Grallaria guatimalensis). In: del Hoyo J., Elliott A., Sargatal J., Christie D.A. \& de Juana E. (eds.). Handbook of the birds of the world alive. Barcelona: Lynx Editions. http://www.hbw.com/node/56885 (Access on 04 November 2016).

Lopes L.E. \& Gonzaga L.P. 2016. Morphological data support the recognition of four species in the genus Sirystes Cabanis \& Heine 1859 (Aves: Tyrannidae). Zootaxa 4127: 401-431.

Mallet-Rodrigues F. \& Pacheco J.F. 2003. O registro supostamente brasileiro de Grallaria guatimalensis roraimae Chubb, 1921. Revista Brasileira de Ornitologia 11: 117-118.

Mattsson B.J., Master T.L., Mulvihill R.S. \& Robinson W.D. 2009. Louisiana Waterthrush (Parkesia motacilla). In: Poole A.F. (ed.). The birds of North America. Ithaca: Cornell Lab of Ornithology. https://doi.org/10.2173/bna.151 (Access on 31 August 2019).

Mayr E. \& Phelps-Jr. W.S. 1967. The origin of the bird fauna of the south Venezuelan highlands. Bulletin of the American Museum of Natural History 136: 269-328.

Milensky C.M., Robbins M.B., Saucier J.R., O'Shea B.J., Radosavljevic A., Davis T.J. \& Pierre M. 2016. Notes on breeding birds from the Guyana highlands with new records from a recent inventory of Mount Ayanganna. Cotinga 38: 64-78.

Naka L.N., Cohn-Haft M., Mallet-Rodrigues F., Santos M.P.D. \& Torres M.F. 2006. The Avifauna of the Brazilian state of Roraima: bird distribution and biogeography in the Rio Branco Basin. Revista Brasileira de Ornitologia 14: 191-232.

Novaes F.C. 1965. Notas sobre algumas aves da Serra Parima, território de Roraima (Brasil). Boletim do Museu Paraense Emílio Goeldi: Nova Série Zoologia 54: 1-10.

Pacheco J.F. \& Agne C.E.Q. 2019. Species lists of birds for South American countries and territories: Brazil. www.museum.lsu. edu/ Remsen/SACCCountryLists.htm (Access on 31 August 2019).

Piacentini V.Q., Aleixo A., Agne C.E., Maurício G.N., Pacheco J.F., Bravo G.A., Brito G.R.R., Naka L.N., Olmos F., Posso S., Silveira L.F., Betini G.S., Carrano E., Franz I., Lees A.C., Lima L.M., Pioli D., Schunck F., Amaral F.R., Bencke G.A., Cohn-Haft M., Figueiredo L.F.A., Straube F.C. \& Cesari E. 2015. Annotated checklist of the birds of Brazil by the Brazilian Ornithological Records Committee. Revista Brasileira de Ornitologia 23: 91-298.

Plenge M.A., Schulenberg T.S. \& Valqui T. 2018. Species lists of birds for South American countries and territories: Peru. www.museum. lsu.edu/ Remsen/SACCCountryLists.htm (Access on 31 August 2019).

Rego M.A., Del-Rio G. \& Silveira L.F. 2014. A taxonomic review of Picumnus exilis (Aves: Picidae) reveals an underestimation of piculet species diversity in South America. Journal of Ornithology 155: 853-867.

Remsen-Jr. J.V., Areta J.I., Cadena C.D., Claramunt S., Jaramillo A., Pacheco J.F., Robbins M.B., Stiles F.G., Stotz D.F. \& Zimmer K.J. A classification of the bird species of South America. American Ornithological Society. http://www.museum.lsu.edu/ Remsen/ SACCBaseline.htm (Access on 31 August 2019).

Robbins M.B., Braun M.J., Milensky C.M., Schmidt B.K., Prince W., Rice N.H., Finch D.W. \& O'Shea B.J. 2007. Avifauna of the upper Essequibo River and Acary Mountains, southern Guyana. Ornitología Neotropical 18: 339-368.

Rodrigues E.B., Aleixo A., Whittaker A. \& Naka L.N. 2013. Molecular systematics and taxonomic revision of the Lineated Woodcreeper complex (Lepidocolaptes albolineatus: Dendrocolaptidae), with description of a new species from southwestern Amazonia, p. 248-252. In: del Hoyo J., Elliott A., Sargatal J. \& Christie D.A. (org.). Handbook of the birds of the world (new species and global index). Barcelona: Lynx Editions. 
Roeder J. \& Moores C. 2007. Bell Tower Birding, separating Louisiana and Northern Waterthrushes. http://belltowerbirding.blogspot. com.br/2007/05/separating-louisiana-and-northern_04.html (Access on 31 August 2019).

Sibley D. 2012. Identification of waterthrushes. http://www. sibleyguides.com/2012/08/identification-of-waterthrushes/ (Access on 31 August 2019).

Wetmore A. \& Phelps-Jr. W.H. 1956. Further additions to the list of birds of Venezuela. Biological Society of Washington 69: 1-12.

Whitaker D.M. \& Eaton S.W. 2014. Northern Waterthrush (Parkesia noveboracensis). In: Poole A.F. (ed.). The birds of North America. Ithaca: Cornell Lab of Ornithology. https://doi.org/10.2173/ bna.182 (Access on 31 August 2019).

Whitney B.M. \& Cohn-Haft M. 2013. Fifteen new species of Amazonian birds, p. 223-239. In: del Hoyo J., Elliott A., Sargatal J. \& Christie D.A. (org.). Handbook of the birds of the world (new species and global index). Barcelona: Lynx Editions.

Zyskowski K., Mittermeier J.C., Ottema O., Rakovic M., O'Shea B.J. Lai J.E., Hochgraf J. \& Au K. 2011. Avifauna of the easternmost tepui, Tafelberg in central Suriname. Bulletin of the Peabody Museum of Natural History 52: 153-180.

Associate Editor: Marcos P. Dantas.

\section{APPENDIX I}

Specimen data of birds collected on Serra da Mocidade, Brazil.

Grallaria guatimalensis - one specimen (data translated from Portuguese of specimen label): Instituto Nacional de Pesquisas da Amazônia (INPA) number 5005, tissue A-19796, female (ovary $8 \times 6 \mathrm{~mm}$; oviduct $3 \mathrm{~mm}$ wide, convoluted; ova minute), no bursa, skull 100\% ossified, stomach containing arthropod parts (saved), $75 \mathrm{~g}$, iris dark brown, maxilla blackish brown, mandible grayish beige with darker tip, toes and tarsi dull pale pink, little fat, no body or tail molt, primary 1 molting both sides, collector Mario Cohn-Haft, preparator Gisiane R. Lima number 3265.

Catharus aurantiirostris - nine specimens, summarized: INPA 5016-5024. Five males (24.5-32 g; left testes $2 \times 1-4 \times 3 \mathrm{~mm}$; skulls $75-100 \%$ ossified; trace [1 individual], little [3], moderate [1] fat), three females (22-27.5 g; ovaries $6 \times 4-8 \times 5 \mathrm{~mm}$, oviduct convoluted [2], straight [1], ova minute; skull 50-95\% ossified; little [2] and heavy [1] fat), and one unidentified sex (27 g; gonads not found; skull 95\% ossified; fat not noted). Stomach contents (saved): arthropod parts (6) and fruit fragments (2). None with bursa or any feather molt. Tissues: A-19754, A-19763, A-19793, A-19813, A-19828, A-19848, A-19869, A-19901, A-19909. All were prepared by Gisiane R. Lima, after collection by various team members. 